A N N A L E S

UNIVERSITATIS MARIAE CURIE-SKŁODOWSKA

LUBLIN - POLONIA

VOL. LXIV, 2

SECTIO C

2009

\title{
PIOTR JADCZYK
}

Institute of Environmental Protection Engineering, Wrocław University of Technology, Wybrzeże Wyspiańskiego 27, 50-370 Wrocław, Poland, e-mail: piotr.jadczyk@pwr.wroc.pl

\section{Foraging strategies of wintering corvids Corvidae in suburban agrocenoses}

Strategie żerowania krukowatych Corvidae

zimujących w podmiejskich agrocenozach

\section{SUMMARY}

The aim of the study was to compare foraging strategies in suburban agrocenoses exercised by rooks Corvus frugilegus, jackdaws Corvus monedula and hooded crows Corvus cornix belonging to two neighbouring but different in size groups related to the city of Wrocław and the town of Brzeg. On selected research areas, rooks, jackdaws and hooded crows, as well as young and adult rooks were counted separately once a week. The size of foraging flocks was also determined. The studies near Wrocław were conducted in 2006-2008 and near Brzeg in 2007-2009.

Rooks constituted $77.6 \%$ of corvids foraging in agrocenoses near Wrocław and $70.7 \%$ of corvids foraging near Brzeg. Jackdaws constituted $18.0 \%$ of corvids foraging near Wrocław and $28.1 \%$ of corvids foraging near Brzeg, whereas hooded crows constituted $4.4 \%$ and $1.2 \%$ respectively $\left(\mathrm{N}_{\text {Wroctaw }}=5,119, \mathrm{~N}_{\text {Brzeg }}=5,694\right.$ birds). Thus, the proportion of jackdaws and hooded crows on suburban feeding grounds was higher than that previously observed in Wrocław and Brzeg. Similarly, the proportion of young birds in the population of rooks was lower in suburban agrocenoses than in that previously observed in urban environments of Wrocław and Brzeg. It was $8 \%$ near Wrocław $(\mathrm{N}=1339)$ and $21 \%$ near Brzeg $(\mathrm{N}=498)$. This was an indication of varied synurbization of rooks, jackdaws and hooded crows and of higher synurbization of adult rooks in comparison with young ones.

Corvids were usually foraging on a variety of fields outside villages, most frequently choosing ploughed fields and grasslands. Rooks were feeding on suburban fields at the beginning of the wintering period more frequently than at the end of the period. In comparison with urban environment, they formed larger foraging groups there and were more often using a strategy of active search food searching. The obtained results indicate a decreasing influence of meteorological 
factors (temperature and the presence of snow cover) on the choice of urban or suburban feeding grounds. This may be one of the consequences of global warming.

K e y w o r d s: rook Corvus frugilegus, jackdaw Corvus monedula, hooded crow Corvus cornix, bird wintering, Silesian avifauna

\section{STRESZCZENIE}

Celem badań było porównanie strategii żerowania w podmiejskich agrocenozach gawronów Corvus frugilegus, kawek Corvus monedula i wron Corvus cornix należących do dwóch sąsiadujących ze sobą, a różniących się wielkością zgrupowań związanych z miastami Wrocław i Brzeg. Na wybranych powierzchniach badawczych raz w tygodniu liczono osobno gawrony, kawki i wrony oraz gawrony młode i dorosłe. Określano także wielkość grup żerowiskowych. Badania pod Wrocławiem prowadzono w latach 2006-2008, pod Brzegiem w latach 2007-2009.

Gawrony stanowiły $77,6 \%$ krukowatych żerujących w agrocenozach pod Wrocławiem i 70,7\% krukowatych żerujących pod Brzegiem. Kawki stanowiły 18,0\% krukowatych żerujących pod Wrocławiem i 28,1\% krukowatych żerujących pod Brzegiem, wrony: odpowiednio 4,4\% i 1,2\% $\left(\mathrm{N}_{\text {Wroclaw }}=5119, \mathrm{~N}_{\text {Brzeg }}=5694\right.$ osobników). Udział kawek i wron na żerowiskach podmiejskich był więc wyższy od stwierdzonego uprzednio we Wrocławiu i w Brzegu. Także udział osobników młodych w populacji gawronów był mniejszy w podmiejskich agrocenozach od stwierdzonego wcześniej w środowiskach miejskich Wrocławia i Brzegu. Wynosił on 8\% pod Wrocławiem $(\mathrm{N}=1339)$ i 21\% pod Brzegiem ( $\mathrm{N}=498)$. Wskazywało to na zróżnicowanie synurbizacji gawronów, kawek i wron oraz większą synurbizację gawronów dorosłych niż młodych.

Krukowate najczęściej żerowały w mozaice pól na obrzeżach wsi, preferując zaorane pola i tereny trawiaste. Gawrony liczniej żerowały na podmiejskich polach na początku niż pod koniec okresu zimowania. W porównaniu ze środowiskami miejskimi tworzyły tu większe grupy żerowiskowe, częściej stosowały strategię aktywnego poszukiwania pokarmu. Uzyskane wyniki wskazują na zmniejszanie się wpływu czynników meteorologicznych (temperatura powietrza i obecność pokrywy śniegowej) na wybór żerowisk miejskich lub podmiejskich. Może to być jedno $\mathrm{z}$ następstw globalnego ocieplenia.

\section{INTRODUCTION}

Literature concerning wintering rooks Corvus frugilegus and accompanying jackdaws Corvus monedula and hooded crows Corvus cornix is quite abundant. Most of the literature focuses on their social roosting (Jadczyk and Jakubiec, 1995). There are few papers, however, on foraging habits of wintering rooks. They present findings of studies conducted in Poland at different periods (Pinowski 1959, Jakubiec 2005, Jadczyk 2008), in Ireland (Macdonald and Whelan 1986), Switzerland (Fankhauser 1994) and Italy (Rolando et al. 1986). The most recent work concerns selected aspects of foraging habits of rooks and accompanying jackdaws Corvus monedula forming a small community in an average-sized town - Brzeg (Jadczyk 2008). Some aspects of rook foraging strategy in various urban environments were also studied in Poznań (Winiecki 2000). Studies on rook foraging in agrocenoses were conducted near Warsaw in 1950's (Pinowski 1959) and near Turew in Wielkopolska region in 1970's (Jakubiec 2005). Other literature works, especially older ones, present some general information on rook foraging habitats (Weissbach 1978). Some new works also present data on density. The data are based on few individual controls of research areas (Biaduń 1998, Walasz et al. 2000, Luniak et al. 2001). 
Therefore, the aim of the present study was to compare foraging strategies exercised in suburban agrocenoses by rooks from two neighbouring communities: a large community related to a big city (Wrocław) and a small community related to an average-sized town (Brzeg).

\section{STUDY AREA}

The studies were conducted in the Odra proglacial valley in the Silesian Lowland, which has the warmest climate in Poland. Observations were conducted on two areas near Wrocław and Brzeg. Area $1\left(6,138 \mathrm{~km}^{2}\right)$ included agrocenoses located $15-18 \mathrm{~km}$ from the Wrocław roosting place (Fig. 1) and area $2\left(26,309 \mathrm{~km}^{2}\right)$ included agrocenoses located $4-8 \mathrm{~km}$ from the Brzeg roosting place (Fig. 2) Winter cereal was prevailing in both research areas. There was also a big proportion of fields ploughed for spring cereal cultivation. There were not many meadows, pastures, stubbles and fallows, especially near Brzeg. More winter rape was cultivated near Brzeg than near Wrocław (Table 1). Villages on area 1 were characterised by more compact development than on area 2. There were almost no crop fields within villages near Wrocław, except for scarce crop fields in Marcinkowice. There were more crops within villages near Brzeg, especially within the village of Lipki. Mid-field woodlots were unevenly distributed on both areas. On area 1, they more frequently occurred along the railway line than along the road, and on area 2, they most frequently occurred near the Odra.

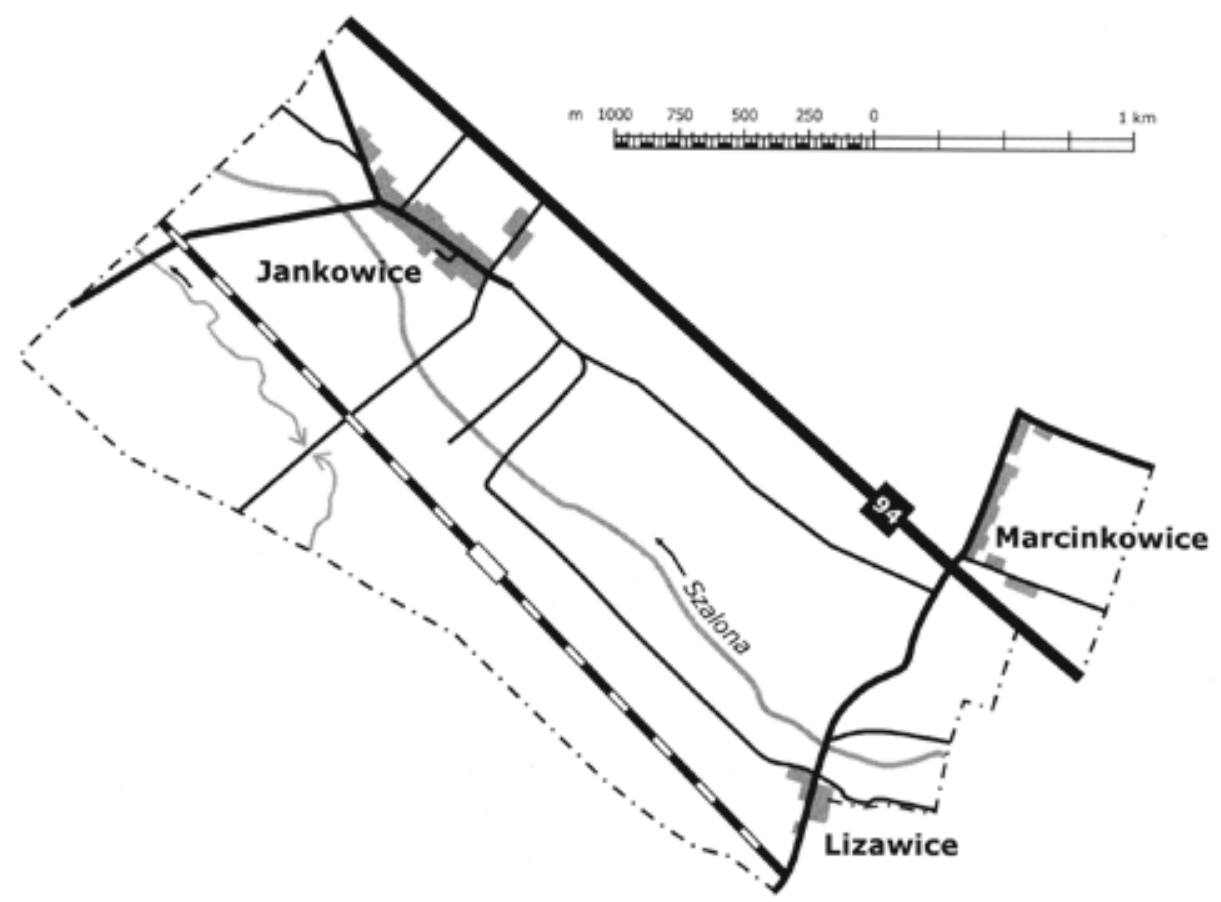

Fig. 1. Study area number 1 (near Wrocław) 


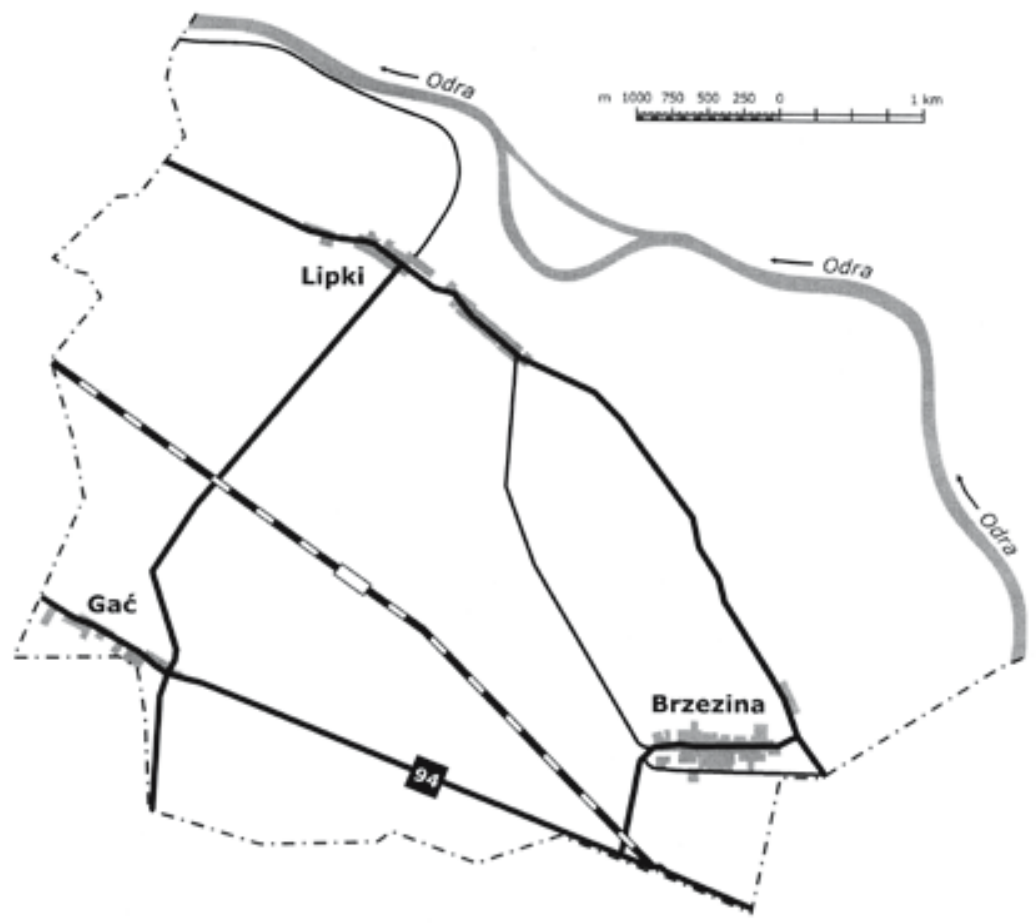

Fig. 2. Study area number 2 (near Brzeg)

Table 1. Crop structure on study areas

\begin{tabular}{|c|c|c|c|c|}
\hline \multirow{3}{*}{ Crop type } & \multicolumn{4}{|c|}{ Relative area proportion [\%] } \\
\hline & \multicolumn{2}{|c|}{ near Wrocław (1) } & \multicolumn{2}{|c|}{ near Brzeg (2) } \\
\hline & $2006 / 2007$ & $2007 / 2008$ & $2007 / 2008$ & $2008 / 2009$ \\
\hline Ploughed & 38 & 24 & 35 & 27 \\
\hline Winter cereal & 40 & 56 & 43 & 38 \\
\hline Meadows and pastures & 4 & 1 & 1 & 3 \\
\hline Fallows and stubbles & 12 & 13 & 1 & 2 \\
\hline Winter rape & 6 & 6 & 20 & 30 \\
\hline
\end{tabular}

\section{METHODS}

Size and species types in the foraging flocks, as well as age structure of the rook population were evaluated by counting rooks, jackdaws and hooded crows separately, as well as young and adult rooks. Subspecies of jackdaws were identified on the basis of neck colouring and the presence of a white collar. Young rooks were differentiated from old ones by plumage on the root of beak or the lack of it. Recorded data also included foraging group size and species, type of crop on feeding grounds, and if the birds were staying within the village, at its boundaries (agrocenoses close to buildings) or outside the village. It was assumed that foraging birds were those who were staying 
on the ground. Birds staying on trees, shrubs, fences, roofs, poles, etc., were considered as passive. Areas were checked once a week by bike or car and partially on foot (Table 2). The total number of working hours spent outdoors was 120 .

Table 2. Study area controls

\begin{tabular}{|l|c|c|c|c|c|}
\hline \multicolumn{1}{|c|}{ Research area } & $\begin{array}{c}\text { Study } \\
\text { season }\end{array}$ & $\begin{array}{c}\text { Number of } \\
\text { controls in } \\
\text { a season }\end{array}$ & $\begin{array}{c}\text { Date of the } \\
\text { first control }\end{array}$ & $\begin{array}{c}\text { Date of the } \\
\text { last control }\end{array}$ & $\begin{array}{c}\text { Average } \\
\text { duration of } \\
\text { control (min.) }\end{array}$ \\
\hline \multirow{2}{*}{$\begin{array}{l}\text { Agrocenoses } \\
\text { near Wrocław }\end{array}$} & $2006 / 2007$ & 18 & 26.10 & 10.03 & 80 \\
\cline { 2 - 6 } & $2007 / 2008$ & 17 & 27.10 & 17.02 & \\
\hline $\begin{array}{l}\text { Agrocenoses } \\
\text { near Brzeg }\end{array}$ & $2007 / 2008$ & 16 & 2.11 & 11.03 & 115 \\
\cline { 2 - 6 } & $2008 / 2009$ & 22 & 31.10 & 30.03 & \\
\hline
\end{tabular}

\section{RESULTS}

Species types in corvid communities foraging in suburban agrocenoses

Corvid communities foraging in agrocenoses included primarily rooks, which constituted $77.6 \%$ of corvids occurring on fields near Wrocław and $70.7 \%$ of corvids on fields near Brzeg. The proportion of jackdaws in these groups was higher on fields near Brzeg (28.1\%) than near Wrocław (18.0\%). Jackdaws feeding on fields near Wrocław and Brzeg represented all the three jackdaw subspecies wintering in Poland (Table 3). The proportions of particular subspecies near Wrocław and Brzeg were similar (differences were not statistically significant at $\mathrm{p}=0.05$ ). The proportion of Corvus monedula monedula in suburban agrocenoses was similar to the one observed in the town of Brzeg in 2006-2008 (the difference was not statistically significant at $\mathrm{p}=0.05$ ). The proportion of Corvus monedula spermologus among jackdaws foraging in agrocenoses was lower and Corvus monedula sommeringii was higher than within the town of Brzeg (the differences were statistically significant at $\mathrm{p}<0.05 ; \chi_{C \text {. m. spermologus }}^{2}=5.5 ; \chi_{C . m \text {. sommeringii }}^{2}=$ 17.2). This shows that urban feeding grounds are preferred by Corvus monedula spermologus, whereas suburban agrocenoses are preferred by Corvus monedula sommeringii. This also indicates different number of individuals synurbized in

Table 3. The proportion of subspecies in the jackdaw population (\%)

\begin{tabular}{|l|c|c|c|c|}
\hline \multicolumn{1}{|c|}{ Research area } & C. m. monedula & C. m. spermologus & C. m. sommeringii & $\mathrm{N}$ \\
\hline Fields near Wrocław & 48 & 11 & 41 & 145 \\
\hline Fields near Brzeg & 45 & 18 & 37 & 51 \\
\hline Fields in total & 47 & 13 & 40 & 196 \\
\hline $\begin{array}{l}\text { The town of Brzeg } \\
\text { (Jadczyk 2008) }\end{array}$ & 48 & 33 & 19 & 405 \\
\hline
\end{tabular}


the populations of these two subspecies. The proportion of hooded crows was higher near Wrocław $-4.4 \%$, than in the region of Brzeg $-1.2 \%\left(\mathrm{~N}_{\text {Wroclaw }}=5119\right.$, $\mathrm{N}_{\text {Brzeg }}=5694$ ).

Average densities of all the three species were higher in agrocenoses near Wrocław than near Brzeg (the differences were statistically significant, $p>0.05$, Table 4). More rooks were foraging in agrocenoses near Wrocław and Brzeg at the beginning rather than at the end of the wintering period. The regression curves were statistically significant (Fig. 3). Average numbers of rooks staying on areas near Wrocław revealed statistically significant differences in the period X-XI 236 individuals and XII-II - 74 individuals (both seasons were analysed together, $\mathrm{t}=2.235, \mathrm{p}=0.03$ ). Statistical significance was also observed in the average number of rooks on fields near Brzeg in the periods X-XI - 189, XII-I - 124, II-III $12(\mathrm{~F}=7.8, \mathrm{p}=0.002)$. As for jackdaws, statistical significance was observed with regard to differences in bird number on areas near Brzeg in the periods X-XII 76 and I-III $-11(\mathrm{t}=2.59, \mathrm{p}=0.009)$. During two research periods on the area near Brzeg, 65 hooded crows were observed in 18 controls in the period X-XII and 6 hooded crows in 20 controls in the period I-III. Dynamic changes in jackdaw and hooded crow numbers during the wintering period on the Wrocław research area did not show differences that would be statistically significant or repetitious.

Young birds constituted $8 \%$ of rooks foraging on fields near Wrocław, whereas the proportion of young birds in the population near Brzeg was much higher, i.e. $21 \%\left(\mathrm{~N}_{\text {Wroclaw }}=5119, \mathrm{~N}_{\text {Brzeg }}=5741\right)$.

Table 4. Density of rooks, jackdaws and hooded crows per $1 \mathrm{~km}^{2}$ of study area near Wrocław and Brzeg

\begin{tabular}{|l|c|c|c|}
\hline \multirow{2}{*}{ Species } & \multicolumn{2}{|c|}{ Density: bird $/ 1 \mathrm{~km}^{2}$} & \multirow{2}{*}{$\mathrm{t}$} \\
\cline { 2 - 3 } & near Wrocław & near Brzeg & \\
\hline Rook & 18.5 & 4.0 & 3.895 \\
\hline Jackdaw & 4.3 & 1.6 & 2.692 \\
\hline Hooded crow & 1.0 & 0.07 & 5.455 \\
\hline
\end{tabular}

Feeding ground location against the village

Rooks, hooded crows and jackdaws were usually foraging on fields in direct proximity to village buildings or among the buildings. Near Brzeg, there were also a few groups foraging far from village buildings (a group of 150 rooks, 340 jackdaws and four hooded crows about $400 \mathrm{~m}$ from the village and 120 rooks and 100 jackdaws $600 \mathrm{~m}$ from the village) and individual birds were observed on a pile of straw half the way between Lipki and Brzeziny (one rook and one hooded crow). Incidental cases of rooks, hooded crows and jackdaws foraging on fields were recorded near Wrocław. These observations were made accidentally 
and were not included the schedule of weekly controls presented in this paper. Rooks, jackdaws and hooded crows were more often gathering near Brzeg than near Wrocław (Table 5). The differences were statistically significant at $\mathrm{p}<0.05$ ). That could be caused by different character of villages near Brzeg and Wrocław. Villages near Brzeg were bigger than those near Wrocław, and they included numerous agrocenoses surrounded by buildings. Villages near Wrocław were characterized by a more compact development with almost no agrocenoses (two crop cultivations within the research area in Marcinkowice).
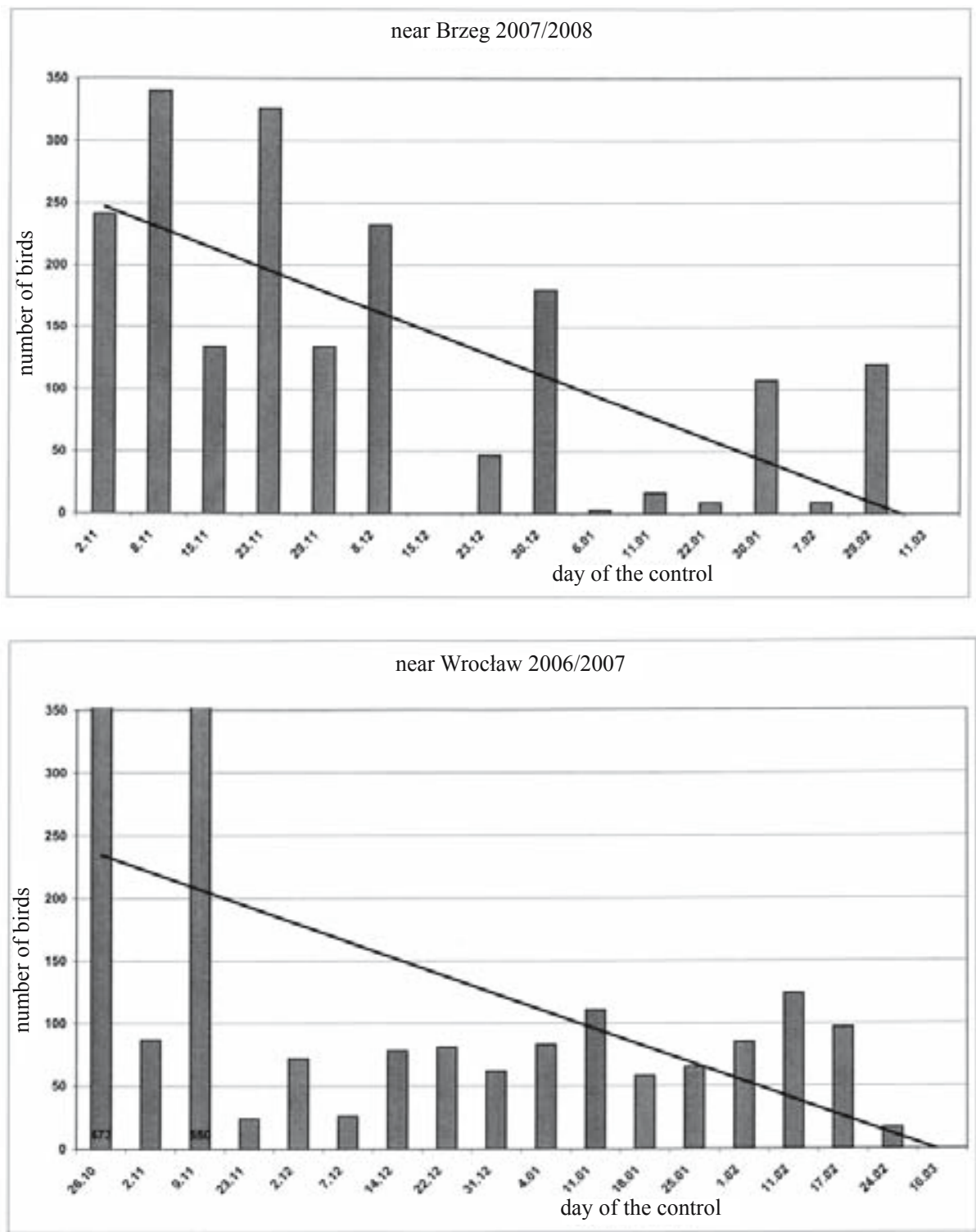

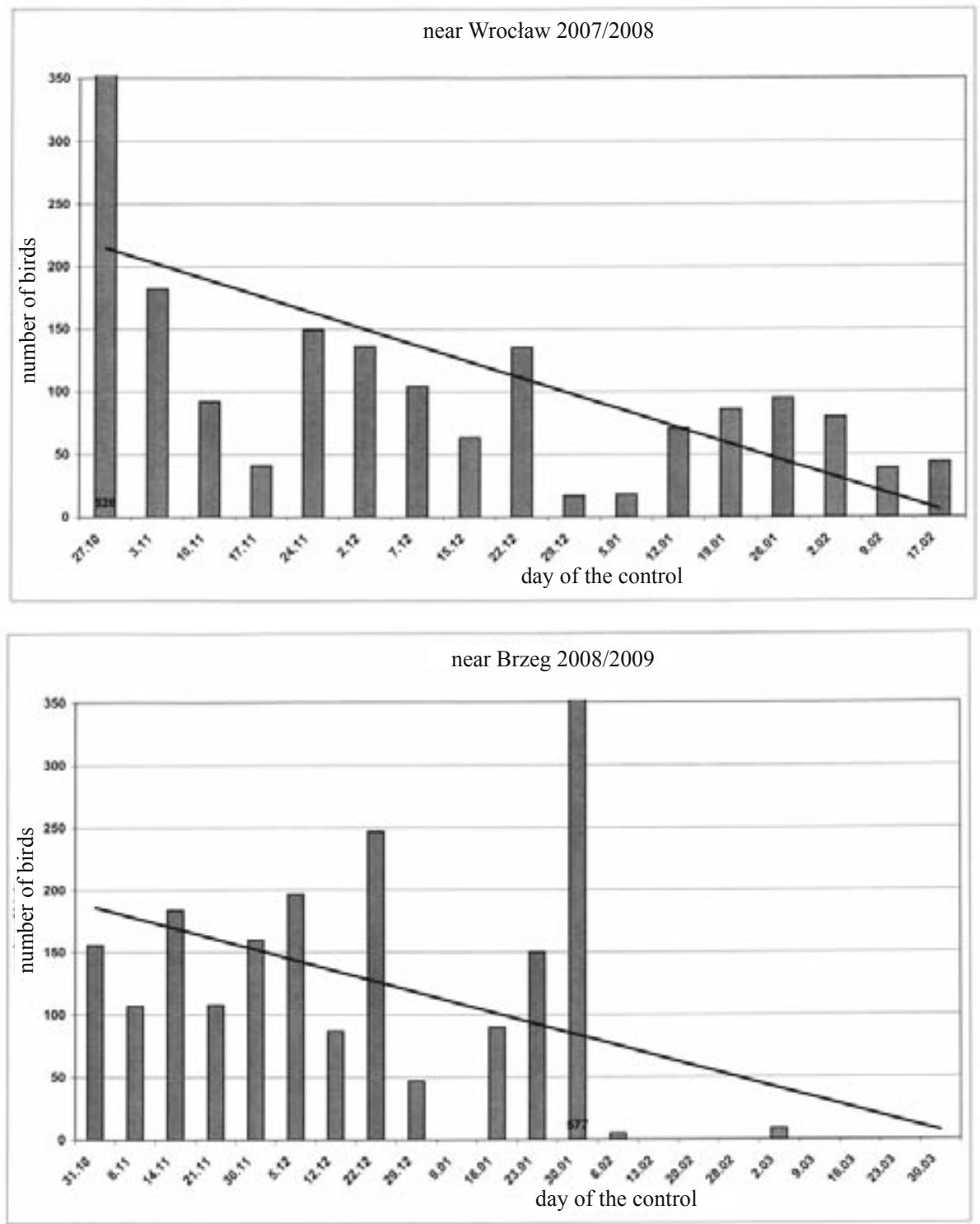

Fig. 3. Dynamic changes in rooks number in the study areas

Judging by the number of species representatives encountered within village development it should be stated that in agrocenoses conditions near Wrockaw, the most synanthropized species is the rook and the least synanthropized is the hooded crow, which was not at all observed within the village $\left(\chi^{2}=14.7\right.$, the differences were statistically significant at $p<0.05$ ). However, hooded crows were frequently observed foraging on a fox farm situated about $200 \mathrm{~m}$ from the compact 
Table 5. Proportion of corvids observed within the village boundaries

\begin{tabular}{|l|c|c|c|c|c|}
\hline \multicolumn{1}{|c|}{ Species } & Near Wrocław & Near Brzeg & $\mathrm{N}_{\text {Wroctaw }}$ & $\mathrm{N}_{\text {Brzeg }}$ & $\chi^{2(\mathrm{p}<0.05)}$ \\
\hline Rook & $6.2 \%$ & $29.5 \%$ & 4045 & 4416 & 626 \\
\hline Jackdaw & $5.6 \%$ & $21.6 \%$ & 1244 & 1622 & 122 \\
\hline Hooded crow & $0.0 \%$ & $42.7 \%$ & 235 & 82 & 100 \\
\hline
\end{tabular}

development of Jankowice and on nearby agrocenoses. Using the same criterion as before, it should be stated that the most synanthropized species in the region of Brzeg was the hooded crow $\left(\chi^{2}=33.9\right.$, statistically significant differences at $\mathrm{p}<0.05$ ), which was observed in Brzeg during the wintering period in 2006-2008 only 10 times [Jadczyk 2008]. Village penetration could be a preliminary phase of the synanthropization process of hooded crows wintering in the region of Brzeg.

\section{Feeding ground preferences}

The number of encounters of rooks (Table 6) and the number of individuals foraging on various crops (Table 7) were varied. Most frequently and in biggest groups rooks were encountered on ploughed lands and on winter cereal. They were also quite frequently encountered on grasslands. Meadows and pastures did not constitute a large part of the agricultural land on the research area, but grass plants could also be found in other places (draining canal borders, pitches, etc.). The comparison of the number of rooks, jackdaws and hooded crows foraging on both research areas on ploughed fields, winter cereal, grass, fallows and winter rape to the crop area indicated that all the three species preferred ploughed fields and grasslands. Rooks, jackdaws and hooded crows were scarce on winter rape and

Table 6. Number of rook observations depending on the crop type

\begin{tabular}{|l|c|c|c|c|c|c|}
\hline \multirow{2}{*}{\multicolumn{1}{|c|}{ Crop type }} & \multicolumn{3}{c|}{ Number of observations } & \multicolumn{3}{c|}{ Percentage of observations } \\
\cline { 2 - 7 } & Wrocław & Brzeg & total & Wrocław & Brzeg & total \\
\hline Ploughed & 65 & 16 & 81 & 33.7 & 28.6 & 32.5 \\
\hline Winter cereal & 46 & 10 & 56 & 23.8 & 17.9 & 22.5 \\
\hline Grass (meadow, pasture) & 39 & 9 & 48 & 20.2 & 16.1 & 19.3 \\
\hline Orchard, garden, yard & 6 & 11 & 17 & 3.1 & 19.6 & 6.8 \\
\hline Fallow, stubble & 6 & 5 & 11 & 3.1 & 8.9 & 4.4 \\
\hline Corn & 4 & 3 & 7 & 2.1 & 5.4 & 2.8 \\
\hline Winter rape & 1 & 1 & 2 & 0.5 & 1.8 & 0.8 \\
\hline Others & 26 & 1 & 27 & 13.5 & 1.8 & 10.8 \\
\hline Total & 193 & 56 & 249 & 100.0 & 100.0 & 100.0 \\
\hline
\end{tabular}


Table 7. Number of rooks depending on the crop type

\begin{tabular}{|l|c|c|c|c|c|c|}
\hline \multirow{2}{*}{\multicolumn{1}{|c|}{ Crop type }} & \multicolumn{3}{c|}{ Number of birds } & \multicolumn{3}{c|}{ Percentage of birds } \\
\cline { 2 - 7 } & Wrocław & Brzeg & total & Wrocław & Brzeg & total \\
\hline Ploughed & 1756 & 2274 & 4030 & 28.7 & 37.8 & 33.2 \\
\hline Winter cereal & 1885 & 2139 & 4024 & 30.8 & 35.6 & 33.2 \\
\hline Grass (meadow, pasture) & 1003 & 800 & 1803 & 16.4 & 13.3 & 14.9 \\
\hline Orchard, garden, yard & 135 & 378 & 513 & 2.2 & 6.3 & 4.2 \\
\hline Fallow, stubble & 99 & 198 & 297 & 1.6 & 3.3 & 2.4 \\
\hline Corn & 132 & 112 & 244 & 2.2 & 1.9 & 2 \\
\hline Winter rape & 51 & 50 & 101 & 0.8 & 0.8 & 0.8 \\
\hline Others & 1058 & 65 & 1123 & 17.3 & 1.1 & 9.3 \\
\hline Total & 6119 & 6016 & 12135 & 100.0 & 100.0 & 100.0 \\
\hline
\end{tabular}

Table 8. Percentage of rooks, jackdaws and hooded crows feeding on certain crops and the proportion of these crops on both research areas together

\begin{tabular}{|l|c|c|c|c|}
\hline \multirow{2}{*}{\multicolumn{1}{|c|}{ Crop }} & \multirow{2}{*}{$\begin{array}{c}\text { Percentage } \\
\text { of the area }\end{array}$} & $\begin{array}{c}\text { rook } \\
\text { N=10255 }\end{array}$ & $\begin{array}{c}\text { jackdaw } \\
\mathrm{N}=3315\end{array}$ & $\begin{array}{c}\text { Pooded crow } \\
\mathrm{N}=266\end{array}$ \\
\cline { 3 - 5 } & & 39 & 38 & 38 \\
\hline Ploughed & 32 & 39 & 37 & 43 \\
\hline Winter cereal & 44 & 18 & 20 & 15 \\
\hline Grass (meadow, pasture) & 2 & 3 & 4 & 2 \\
\hline Fallow, stubble & 5 & 1 & 0.2 & 2 \\
\hline Rape & 17 & 16993 & 7071 & 312 \\
\hline$\chi^{2}$ & & & & \\
\hline
\end{tabular}

fallows, even in relation to their small area (Table 8 , differences were statistically significant).

Size of foraging flock

Rooks, jackdaws and hooded crows were forming foraging flocks of 3-600 individuals. The average number of rooks in the group was 36 individuals on fields near Wrocław and 69 on fields near Brzeg $\left(\mathrm{N}_{\text {Wroctaw }}=109\right.$ groups, $\mathrm{N}_{\text {Brzeg }}=61$ groups, $\mathrm{t}=2.65, \mathrm{p}=0.005$, the difference was statistically significant). The average number of all corvids in the group was 48 individuals on fields near Wrockaw and 94 on fields near Brzeg ( $\mathrm{t}=2.89, \mathrm{p}=0.002$, the difference was statistically significant). Thus, larger foraging groups were formed by corvids belonging to a small community related to an average-sized town than by corvids belonging to a large 
Table 9. Average size of flocks foraging within villages and at village boundaries (the differences were statistically significant at $\mathrm{p}>0.05$ )

\begin{tabular}{|c|c|c|c|c|}
\hline \multirow{2}{*}{$\begin{array}{l}\text { Average number } \\
\text { in a group }\end{array}$} & \multicolumn{2}{|c|}{ Near Wrocław } & \multicolumn{2}{|c|}{ Near Brzeg } \\
\hline & $\begin{array}{l}\text { within the } \\
\text { village }\end{array}$ & $\begin{array}{l}\text { at village } \\
\text { boundaries }\end{array}$ & $\begin{array}{l}\text { within the } \\
\text { village }\end{array}$ & $\begin{array}{l}\text { at village } \\
\text { boundaries* }\end{array}$ \\
\hline Rooks & 9 & 45 & 43 & 100 \\
\hline $\mathrm{t}$ & \multicolumn{2}{|c|}{4.5} & \multicolumn{2}{|c|}{2.7} \\
\hline Corvids & 12 & 61 & 56 & 142 \\
\hline $\mathrm{t}$ & \multicolumn{2}{|c|}{5.3} & \multicolumn{2}{|c|}{3.1} \\
\hline Number of groups (N) & 25 & 84 & 30 & 31 \\
\hline
\end{tabular}

* including two groups foraging far from buildings ( $400 \mathrm{~m}$ and $600 \mathrm{~m}$ )

community of a big city. Both near Wrocław and Brzeg, groups feeding within the village development were smaller than groups feeding at village boundaries. In Brzeg, they were also Brzeg smaller than those far from the village (Table 9).

Individual rooks ( $1-2$ birds) on the observed feeding grounds were seen very rarely: 47 individual birds per 4,045 rooks on fields near Wrocław (1\%) and 5 individual birds per 4,416 rooks on fields near Brzeg $(0.1 \%)$. Thus, the occurrence of individual birds on feeding grounds was more frequent among rooks belonging to large communities related to a big city that among birds of a small community related to an average-sized town (the difference was statistically significant at $\mathrm{p}=0.05, \chi^{2}=37.8$ ).

Individual rooks observed on feeding grounds constituted $9.2 \%$ of birds staying within villages near Wrocław and $0.6 \%$ of birds staying at village boundaries. The difference was statistically significant $\left(\chi^{2}=148, p<0.05\right)$. Straying from the foraging group was much rarer among rooks near Brzeg: four individual birds per 1,303 within the village and one individual bird (halfway between Lipki and Brzeziny) per 3,112 birds observed at the village boundaries and far from the village.

\section{Feeding activity}

The proportion of rooks, hooded crows and jackdaws showing feeding activity indicated differences which were statistically significant $\left(\chi_{\text {Wroctaw }}^{2}=\right.$ $\left.131.5, \chi_{\text {Brzeg }}^{2}=39.1\right)$. The highest feeding activity was observed in jackdaws and the lowest in hooded crows. The number of rooks showing feeding activity was higher on fields near Wrocław than near Brzeg (the differences were statistically significant at $\mathrm{p} \leq 0.05$, Table 10). The number of jackdaws showing feeding activity in populations near Wrocław and near Brzeg was almost identical (the 
difference was not statistically significant at $\mathrm{p}=0.05$ ). The proportion of hooded crows showing feeding activity was higher near Brzeg compared to Wrocław. However, the difference was not statistically significant at $\mathrm{p}=0.05$, which makes it impossible to state if it was caused by different environmental conditions or insufficient size of the statistical trial. Hooded crows that occurred near Wrocław were frequently using a constant source of food, i.e. the fox farm in Jankowice. There were always several birds on that area.

Table 10. Proportion of individuals showing feeding activity in the population

\begin{tabular}{|l|c|c|c|c|c|}
\hline \multirow{2}{*}{ Species } & \multicolumn{2}{|c|}{ Fields near Wrocław } & \multicolumn{2}{|c|}{ Fields near Brzeg } & \multirow{2}{*}{} \\
\cline { 2 - 5 } & $\begin{array}{c}\text { proportion of } \\
\text { individuals showing } \\
\text { feeding activity }\end{array}$ & $\mathrm{N}$ & $\begin{array}{c}\text { proportion of } \\
\text { individuals showing } \\
\text { feeding activity }\end{array}$ & $\mathrm{N}$ & $\chi^{2}$ \\
\hline Rook & $88 \%$ & 4386 & $76 \%$ & 5030 & 40.9 \\
\hline Jackdaw & $91 \%$ & 1869 & $92 \%$ & 1642 & 0.08 \\
\hline Hooded crow & $56 \%$ & 260 & $70 \%$ & 70 & 1.917 \\
\hline
\end{tabular}

The effect of meteorological factors on the number of rooks, jackdaws and hooded crows foraging in suburban agrocenoses

The number of rooks feeding on fields near Wrocław was to a certain extent dependent on the temperature. They appeared in larger numbers at higher temperatures, and in smaller numbers at lower temperatures. Such a correlation was not observed in rooks foraging on fields near Brzeg. A smaller distance between the roosting place and suburban agrocenoses of rooks wintering in Brzeg could be the cause of more frequent migration between urban and suburban feeding grounds of these birds compared to birds wintering in Wrocław. Values of the Pearson linear correlation coefficient $r$ showed that relative air humidity, daily amount of atmospheric fall and wind speed did not influence the number of

Table 11. The Pearson linear correlation coefficient $r$ between the number of rooks, jackdaws and hooded crows on research areas and meteorological factors

\begin{tabular}{|c|c|c|c|c|c|c|}
\hline Species & Study area & $\begin{array}{c}\text { Mean tem- } \\
\text { perature }\end{array}$ & $\begin{array}{c}\text { Minimal } \\
\text { temperature }\end{array}$ & $\begin{array}{c}\text { Relative } \\
\text { humidity }\end{array}$ & $\begin{array}{c}\text { Amount } \\
\text { of falls }\end{array}$ & $\begin{array}{c}\text { Wind } \\
\text { speed }\end{array}$ \\
\hline \multirow{2}{*}{ Rook } & near Wrocław & 0.43 & 0.40 & 0.25 & 0.11 & -0.13 \\
\cline { 2 - 7 } & near Brzeg & 0.23 & 0.24 & -0.04 & -0.09 & -0.05 \\
\hline \multirow{2}{*}{ Jackdaw } & near Wrocław & 0.05 & 0.05 & 0.08 & -0.09 & -0.03 \\
\cline { 2 - 7 } & near Brzeg & 0.16 & 0.19 & -0.33 & -0.05 & 0.06 \\
\hline \multirow{2}{*}{ Hooded crow } & near Wrocław & -0.07 & -0.08 & -0.27 & -0.07 & 0.13 \\
\cline { 2 - 7 } & near Brzeg & 0.15 & -0.16 & 0.01 & -0.007 & -0.12 \\
\hline
\end{tabular}


rooks foraging in suburban agrocenoses. Temperature, relative air humidity, daily amount of atmospheric fall and wind speed did not have a significant influence on the number of jackdaws and hooded crows foraging in suburban agrocenoses. The value of the Pearson correlation coefficient $r$ between relative humidity and the number of jackdaws foraging on fields near Brzeg $(-0.33)$ was probably accidental (Table 11).

The average number of rooks foraging on fields near Wrocław and Brzeg on days without snow cover was higher than the average number of rooks foraging on fields on days with snow cover (Table 12). In case of jackdaws and hooded crows, differences in their numbers with regard to days with and without snow cover showed a different tendency. Apart from that, differences between average numbers of birds near Brzeg were statistically insignificant. Statistical significance of differences between average numbers of birds was not assessed due to a small number of controls on days with snow cover $(\mathrm{N}=3)$.

Tab. 12. Average number of rooks, jackdaws and hooded crows on research areas on days with and without snow cover

\begin{tabular}{|l|c|c|c|}
\hline \multirow{2}{*}{ Species } & Study area & Without snow cover & With snow cover \\
\hline \multirow{2}{*}{ Rook } & near Wrocław & 119 & 57 \\
\cline { 2 - 4 } & near Brzeg & 113 & 68 \\
\hline \multirow{2}{*}{ Jackdaw } & near Wrocław & 27 & 19 \\
\cline { 2 - 4 } & near Brzeg & 35 & 75 \\
\hline \multirow{2}{*}{ Hooded crow } & near Wrocław & 4 & 6 \\
\cline { 2 - 4 } & near Brzeg & 2 & 3 \\
\hline \multirow{2}{*}{ Number of days(N) } & near Wrocław & 32 & 6 \\
\cline { 2 - 4 } & near Brzeg & 32 & 3 \\
\hline
\end{tabular}

\section{DISCUSSION}

The proportion of particular corvid species foraging on agrocenoses near Wrocław and Brzeg was different from the previously recorded one within Wrocław and Brzeg. The proportion of jackdaws in Wrocław in 1988-1990 was 6-8\% and in Brzeg in 2006-2008 it was 10\%. The proportion of hooded crows in Wrocław was $0.1 \%$ and in Brzeg hooded crows were seen 10 times in the period of two winters (Jadczyk 1994, 2008). Thus, the proportion of rooks foraging on fields near Wrocław and Brzeg was lower than the previously observed one occurring within these cities. However, the proportion of jackdaws and hooded crows was higher. This indicated higher synurbization of wintering rooks in comparison with jackdaws and hooded crows. 
Density of rooks, jackdaws and hooded crows had been previously studied in various envronments near Poznań. The highest density was observed on areas with buildings and vegetable cultivation. Average density was observed on scattered fields of individual farmers and the lowest on areas with prevailing monocultures (Górski 1976). Density of the three species near Wrocław was the most similar to the one observed on areas dominated by scattered crop fields and by monocultures in case of Brzeg. The proportion of monocultures in the total crop area near Brzeg was higher than that near Wrocław. Thus, the obtained results and data provided by Górski (1976) show that wintering corvids prefer a traditional varied agricultural landscape rather than monocultures.

Corvids observed on fields near Wrocław and Brzeg were foraging mainly at village boundaries. The biggest crop fragmentation was observed in that region on both research areas. Feeding grounds characterized by high crop fragmentation were also preferred by rooks in the area of Turew (Jakubiec 2005). On the other hand, the number of rooks in agrocenoses with numerous trees near Warsaw was several-fold lower that in agrocenoses with scarce trees (Pinowski 1959). This observation was the basis of a hypothesis that a larger number of trees causes that passive cooperation in searching for food is more difficult for rooks. Agrocenoses of the highest tree density near Wrocław and Brzeg were situated far from village boundaries. Therefore, rook density could be influenced by distance from the village, crop fragmentation and tree density, or only by some of these factors. Another factor influencing the choice of feeding grounds could be related to the fact that village areas near Wrocław and Brzeg were the least frequently visited by birds of prey (mainly common buzzards Buteo buteo and kestrels Falco tinnunculus). However, rooks were not purposefully fed by inhabitants of villages near Wrocław and Brzeg, as the case is in the city of Wrocław and Brzeg. Therefore, passive waiting for food given by people could not be the motive for foraging in the proximity of buildings.

Choosing grassland for foraging observed in the rook population near Wrocław and Brzeg was also observed by other authors (Rolando et al. 1998, Macdonalds and Whelan 1986, Fankhauser 1994). Rooks wintering in Bern, Switzerland were spending up to $90 \%$ of their feeding time on meadows and pastures. Similarly, over $90 \%$ of rooks foraging on agricultural lands in Ireland were observed on grasslands and stubbles (Macdonalds and Whelan 1986, Fankhauser 1994). Grasslands were also the main feeding grounds for rooks of urban environments in Brzeg (Jadczyk 2008).

Similar difference in foraging group size observed on fields near Wrocław and Brzeg (3-600 birds) were also observed near Turew (3-1,200 birds) by Jakubiec (2005). Both in Lower Silesia and Wielkopolska region, the biggest groups of corvids were formed during the migration period. Differences were smaller in the wintering period. The average size of a foraging flock on fields near Wrocław 
and Brzeg was smaller than the average size of flocks foraging in multifamily residential areas in Brzeg (7.8-12.8). Smaller foraging communities in that area resulted from high grassland fragmentation related to varied density of buildings (Jadczyk 2008).

Results of the studies presented in this paper showed that rooks were more often staying outside foraging communities within the village development rather than at its boundaries. In multifamily residential areas in Brzeg, the number of encounters of individually foraging rooks was increasing together with development density and proximity of the town centre (Jadczyk 2008).

Feeding activity of rooks staying on fields near Wrocław and Brzeg was higher than that of birds foraging on multifamily residential areas in Brzeg. The smaller distance to the city centre and higher building density, the lower the proportion of birds looking for food in an active way. Higher feeding activity of rooks on suburban fields compared to urban environment was also observed in Poznań. That could be caused among other things by deliberate feeding of rooks by inhabitants of the city, which had been also observed in Vienna (Grüll 1981). No deliberate rook feeding was observed near Wrocław and Brzeg, whereas in the city of Wrocław and Brzeg the phenomenon was quite frequent.

Larger number of foraging rooks in suburban agrocenoses during milder periods of winter had already been observed by other authors (Grodziński 1971, Górski 1976, Grüll 1981, Konstantinov et al. 1982, Schramm 1985, Winiecki 2000). Numerous authors also observed increased rook migration from suburban fields to the urban environment in the period of severe frost and snow cover persistence (Gloger 1833, Górski 1976, Grodziński 1976, Winiecki 2000). Initially, the presence of rooks in urban environments was related to the periods of the most severe frost and the thickest snow cover (Gloger 1833, Pax 1925). With time, rooks have been undergoing the process of synurbization (Jadczyk and Jakubiec 1995). Detailed research whose results are presented in this paper indicate a decreasing role of temperature and the presence of snow cover in selection of feeding grounds. This phenomenon is probably caused by milder winters resulting from global warming, rather than by rook adaptation to foraging in agrocenoses in spite of frost and snow cover.

The obtained results and data from literature suggest that in the suburban agricultural landscape, diversified fields at village boundaries are the most frequently selected feeding grounds by corvids. Ploughed fields and grasslands (meadows, pastures, field paths etc.) are especially attractive for foraging birds. Rooks more frequently forage on fields at the beginning of the wintering period rather than at the end of the period. Foraging strategies of corvids wintering in large communities related to a big city or small communities of an average-sized town and feeding in urban environments and suburban agrocenoses are quite similar. Some aspects of these strategies, however, undergo modifications 
depending on the environment structure. The choice of a rural or urban habitat during foraging depends mainly on preferences of particular species, subspecies, age groups or perhaps on local breeding populations that may be more or less synanthropized. The obtained results show a decreasing role of meteorological factors (temperature and the presence of snow cover) in selection of urban or rural feeding grounds. This may be one of the consequences of global warming.

\section{ACKNOWLEDGEMENTS}

The author is grateful to MSc Marek Stajszczyk for his diligent conduct of field research on the study area near Brzeg in the winter season of 2007/2008.

\section{REFERENCES}

1. Biadun W. 1998. The rook, Corvus frugilegus L., in Lublin - breeding population and wintering. [In:] T. Bartczak, P. Indykiewicz (eds.) Urban Fauna, 173-178. Wyd. ATR, Bydgoszcz [In Polish].

2. Fankhauser T. 1994. Raumnutzung und Nahrungswerb von sesshaften Saatkrähen Corvus frugilegus bei Bern im Winter. Der Ornithologische Beobachter 91: 173-193.

3. Gloger C. L. 1833. Schlesiens Wierbelthier-Fauna, Breslau.

4. Górski W. 1976. Investigations on birds wintering in fields near Poznań. Acta Ornithologica, 16: 79-116 [In Polish].

5. Grodziński Z. 1971. Daily flights of Rooks Corvus frugilegus Linnaeus, 1758 and Jackdaws Corvus monedula Linnaeus 1758 wintering in Cracow. Acta Zool. Cracov. 16: 735-772.

6. Grodziński Z. 1976. Rooks Corvus frugilegus Linnaeus, 1758, in one of the Cracow parks. Acta Zool. Cracov. 21: 464-500.

7. Grüll A. 1981. Das Räumliche Activitätsmuster der Saatkrähe (Corvus frugilegus L.) im Laufe des Winters in Wien und Umgebung. Egretta, 24, Sonderh.: 39-63.

8. Jadczyk P., Jakubiec Z. 1995. Winter roosts of Rooks Corvus frugilegus in Europe. Przegląd Zoologiczny 39: 297-312 [In Polish].

9. Jadczyk P. 1994. Winter roosting of Rooks Corvus frugilegus in Wrocław. Acta Ornithologica 29: 39-47.

10. Jadczyk P. 2008. The Winter roostings of corvids Corvidae in Brzeg. [In:] P. Indykiewicz, L. Jerzak, T. Bartczak (eds). Urban Fauna. Protect the Biotic Diversity of Towns. SAR Pomorze, Bydgoszcz, 419-426.

11. Jakubiec Z. 2005. Habitat use and daily activity of foraging Rooks Corvus frugilegus in the agricultural landscape in Wielkopolska. [In:] L. Jerzak., B. P. Kavanagh, P. Tryjanowski. (eds) [Corvids in Poland], Bogucki Wyd. Nauk., Poznań.

12. Konstantinov V. M., Babenko V. G., Barysheva I. K. 1982. Numbers and some ecological features of synanthropic populations of synanthropic populations of the Corvidae under the conditions of intensive urbanization. Zool. Zhurn. 61: 1837-1845.

13. Luniak M., Kozłowski P., Nowicki W., Plit W. 2001. The Atlas of Warszawa. Part 8. Birds of Warszawa. Polish Academy of Science. Stanisław Leszczycki Institute of Geography and Spatial Organization, Warszawa [In Polish]. 
14. Macdonald R. A., Whelan J. 1986. Seasonal variations in feeding range and flock structure of the Rook Corvus frugilegus in eastern Ireland. Ibis 128: 540-557.

15. Pax F. 1925. Wirbelfauna von Schlesien. Berlin.

16. Pinowski J. 1959. Factors influencing the number of feeding rooks (Corvus frugilegus frugilegus L.) in various field environments. Ekologia Polska A, 7, 16: 435-482.

17. Rolando A., Peila P., Marchisio M. 1998. Foraging behaviour and habitat use in corvids wintering on farmlands in northern Italy. Avocetta 22: 56-64.

18. Schramm A. 1985. Untersuchungen über den Aktionsradius von Corviden im Winterquartier. Der Falke 32: 48-50.

19. Walasz K. (ed.) 2000. The Atlas of Wintering Birds in Małopolska. Małopolska Ornithological Society, Kraków [In Polish].

20. Winiecki A. 2000. The wintering strategy of Rooks Corvus frugilegus LINNAEUS 1758, in Poznań, west Poland. Acta Zool. Cracov. 43 (1-2): 135-164. 